\title{
鼻咽腔血管線維腫再発例
}

一 Le Fort I 型骨切り術による治療一

山本 典生・岸本 誠司* $\cdot$ 北村 溥之・高北 晋一
松本 功・前谷 俊樹 $\cdot$ 岩橋 由佳・宮崎 眞和

\section{Relapsing Juvenile Nasopharyngeal Angiofibroma Treated by Le Fort I Osteotomy}

\author{
Norio Yamamoto, Hiroyuki Kitamura, Shinichi Takagita, Isao Matsumoto, \\ Toshiki Maetani, Yuka Iwahashi and Masakazu Miyazaki \\ (Tenri Hospital)
}

Seiji Kishimoto

(National Cancer Center Hospital East)

\begin{abstract}
Juvenile nasopharyngeal angiofibroma is a benign tumor with rich blood flow, usually observed in young males. Though it should be excised surgically, the operation requires a broad operation field to achieve less blood loss, and a functionally and cosmetically sound method. Here, we report an extensively relapsing juvenile nasopharyngeal angiofibroma, excised with midfacial degloving and Le Fort I osteotomy.

A 16-year-old boy was admitted to our hospital with a right side relapsing juvenile nasopharyngeal angiofibroma. The tumor extended to the infratemporal fossa, sphenopalatine fossa, paranasal sinus and the nasopharynx. Preoperative embolization of the feeding artery could not be performed because his right external carotid artery was ligated in a previous operation 1 year earlier. We performed a midfacial degloving and a Le Fort I osteotomy. The tumor was completely excised. Blood loss was $2250 \mathrm{~g}$, and no scar was noted on his face.
\end{abstract}

Key words : juvenile nasopharyngeal angiofibroma, Le Fort I osteotomy, midfacial degloving

はじめに

鼻咽腔血管線維腫は若年男子に好発する血流に富む良 性腫瘍で，治療法は外科的切除が第一選択となるが，出 血の制御のために広い術野を確保すると同時に，若年者 であることを考慮した機能的にも形態的にも合併症の少 ない術式を選択する必要がある，今回我々は，血管線維 腫の広範な再発例に対して, midfacial degloving と Le Fort I 型骨切り術とを行い, 出血量を最小限に抑兄,
美容的にも満足のいく腫瘍摘出が可能であったので報告 する.

\section{症例}

患者 : 16歳, 男性.

主訴：右鼻閉，右鼻出血.

現病歴 : 平成 7 年頃より右鼻閉を自覚するようになっ た. 
同年11月，近医を受診し，右鼻腔腫瘍の診断で摘出術 を受けた。病理診断は線維腫であった。

平成 9 年 8 月頃より, 右鼻出血認画像上再発を疑 い，同医にて経上顎洞的に摘出を試みられたが，出血が 多く，術中に右外頸動脈を結紮し，止血はできたが，完 全に摘出でさなかった。この際の病理診断で, 血管線維 腫と診断された。

以後，同医で経過観察されていたが，平成10年 4 月, 転居のため当科に紹介された。

既往歴：特記事項なし.

現症 : 初診時, 右鼻腔内に易出血性の腫瘍が充満し, また，右上靧洞前壁は欠損して打り，右犬歯窩より右上 顎洞内に充満する腫瘍が観察できた。

\section{検査所見}

血管造影(図 1 ): 右外頸動脈の造影では上甲状腺動脈, 舌動脈は造影されるが，前医で外頸動脈結紮をしている ため顔面動脈，顎動脈などは明らかではなく，腫瘍の濃 染像子明らかではない。これ対して，右内頸動脈の造
影では栄養血管は明らかではないが，上咽頭から鼻腔の 腫瘍に濃染像が認められた。この結果, 術前に栄養血管 の塞栓は不可能と判断し，施行しなかった。

MRI，CT(図 2)：右側頭下窩, 翼口蓋窩, 篩骨洞, 上顎洞，蝶形骨洞，鼻腔を占め，強く造影される腫瘍を 認めた。外側は，内側翼突筋にまで及んでいた。

\section{手術所見，経過}

これらの検査より, Sessions ら1)の分類で stage $\mathbb{I C}$, と判断し手術を施行した。手術は術前に $1600 \mathrm{ml}$ の自己 血貯血を行い, 気管切開の上, 低血圧麻醉で施行した。 アプローチは歯眼部に両側にわたる切開を入れて, 上顎 骨前壁を十分露出して，さらに外鼻軟骨を持ら上げた (midfacial degloving). 次に, 骨切り前にあらかじめチ タンプレートで固定する穴を開けた後，Le Fort I 型の 骨折線に沿って上顎骨を切断し, 鼻中隔もその基部で切 断し, 開創器で上顎骨を上下に開創した (Le Fort I 型 骨切り術) (図 3 )。骨切りの際, 上顎骨を後方をで一度 飞切らず，両側口蓋動脈を損傷しないように，翼状突起

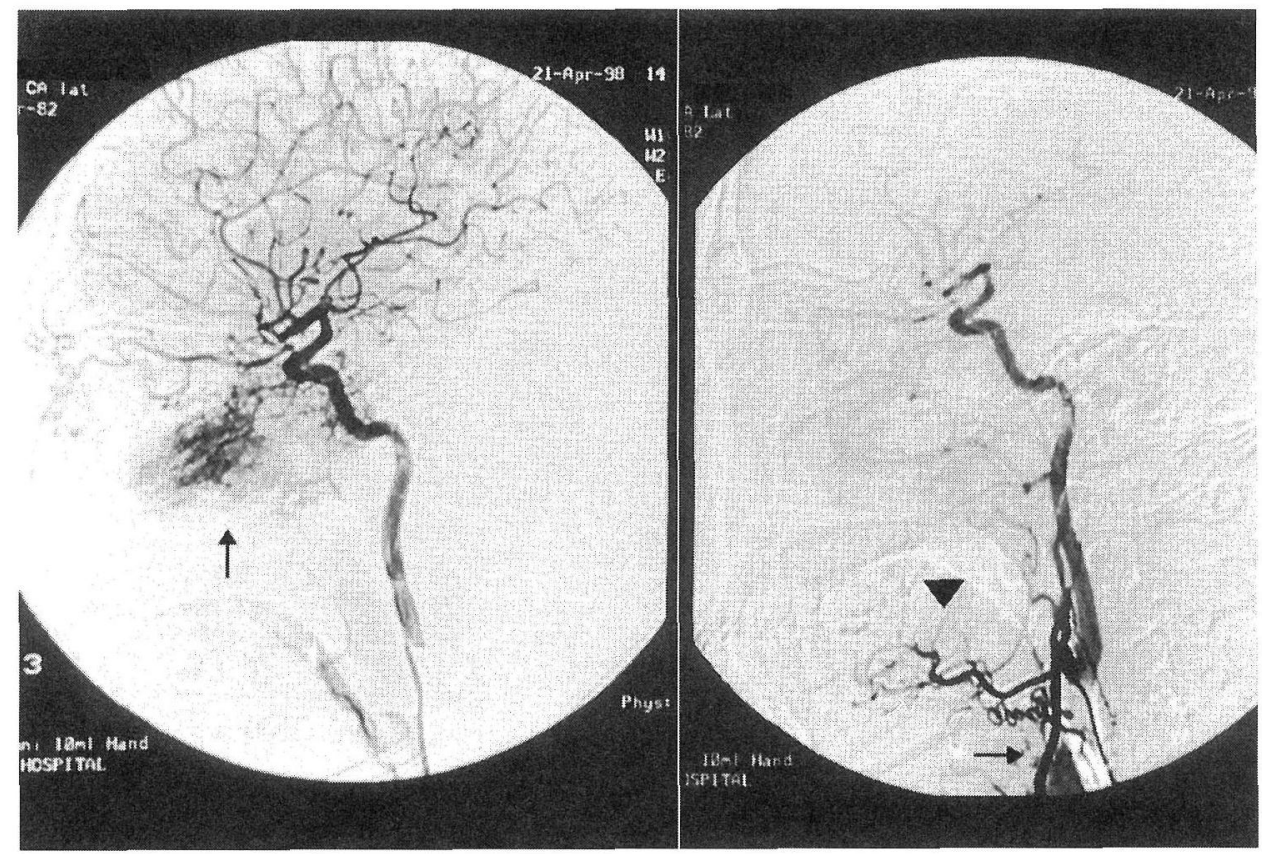

図 1 血管造影

左 : 右内頸動脈造影

$\uparrow:$ 腫瘍濃染像 (栄着血管は明らかではない)

右：右外頸動脈造影(腫瘍濃染は認められない，また，顎動脈などは造影されていない)

$\nabla:$ 舌動脈, $\rightarrow:$ 外頸動脈 


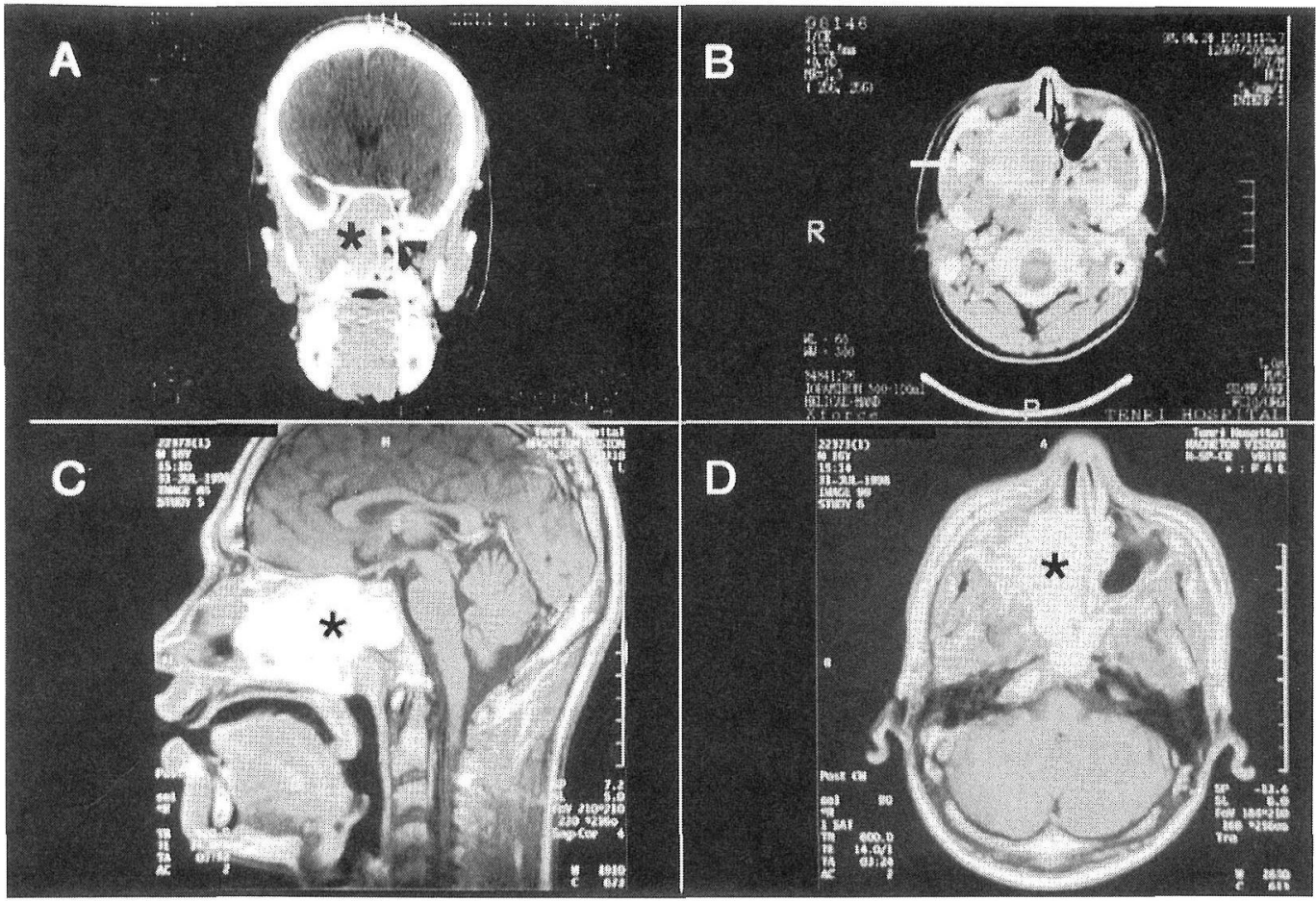

図 $2 \mathrm{~A}$ : 術前造影 CT 冠状断 $*$ : 腫瘍

$\mathrm{B}$ : 術前造影 CT 軸位断 $\Rightarrow$ : 腫瘍

$\mathrm{C}$ ：術前 MRI 矢状断 $(\mathrm{T} 1$ 強調，ガドリニウム造影）＊：腫瘍

$\mathrm{D}$ ：術前 MRI 軸位断 (T1 強調，ガドリニウム造影）＊：腫瘍

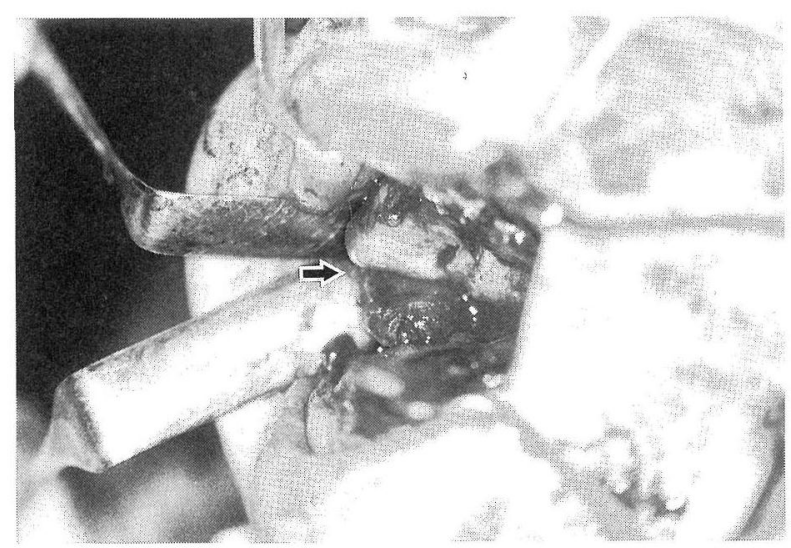

図 3 術中所見 (midfacial degloving, Le Fort I 型骨切り術後) $\Rightarrow$ : 腫瘍

の部分は骨折させて口盍を下方に拈とし開創した，次い でリガクリップ®で止血しながら腫瘍を摘出した。腫 瘍摘出の際に，患側の口蓋動脈は損傷したが，健側の口 蓋動脈は温存できた。腫瘍は外側は内側翼突筋に癒着し
て特り, また内側も中鼻甲介, 鼻中隔後端の粘膜とは癒 着していた。後方は, 後鼻孔, 蝶形骨洞に腫瘍がはまり

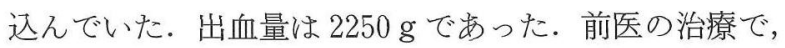
右上顎洞前壁が欠損していたため, 摘出後の上顎骨の固 定は左上顎洞前壁のみに対して，2 本のチタンプレート で行った（図４）。術後, 咬合不全, 開口障害などは生じ て括らず，また，MRI上，肉芽の増生，リガクリッ プ®によるアーチファクトはみられるが, 再発は認めら れない(図 4 )。

摘出した標本の大ささは, $7.5 \times 5 \times 3.5 \mathrm{~cm}$, 割面は白 色均一で, 病理標本は, 壁の薄い血管の増生と線維性基 質の増生を認める血管線維腫の像であった(図 5 ).

\section{考察}

鼻咽腔血管線維腫は，若年男性の鼻咽腔に好発する良 性の腫瘍であり，血流に富んだ腫瘍であるため，光の治 療にあたっては, 年齢や根治性など様々な要因を勘案し なければならない。鼻咽腔血管腫の治療方法としては, 


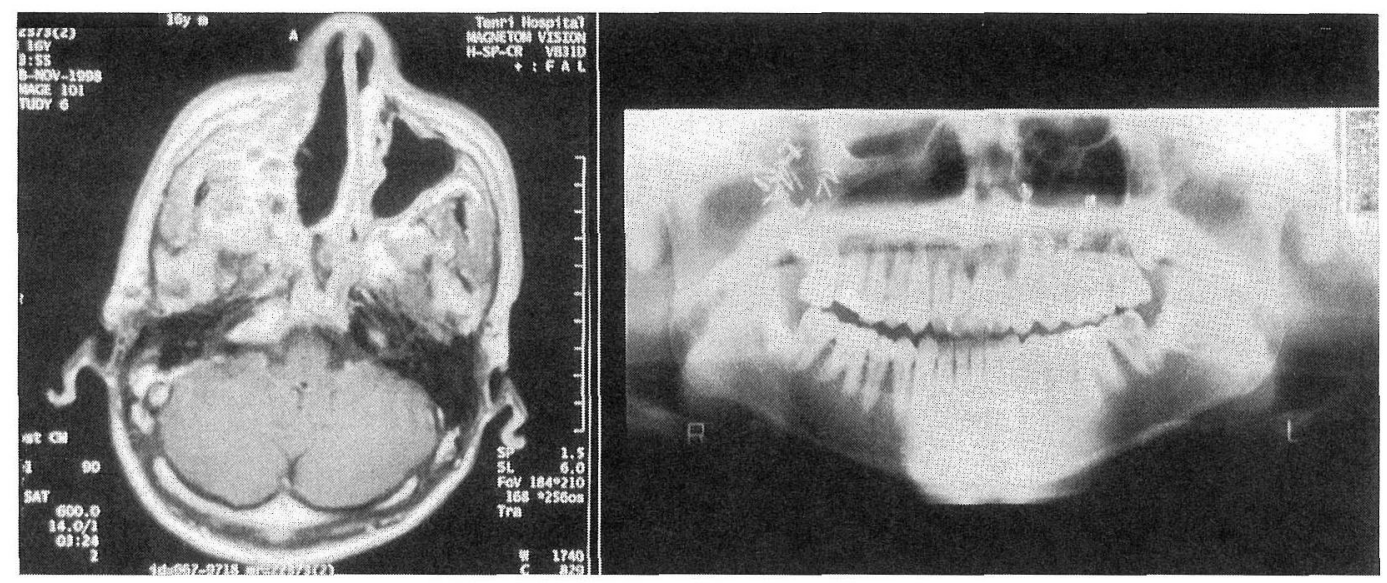

図 4 右: 術後 MRI 軸位断( $\mathrm{T} 1$ 強調, ガドリニウム造影) 凬瘍の再発は認めない.

左：術後パノラマレントゲン 左上顎洞前壁はチタンプレートで固定している，骨の壊死などは認めない。
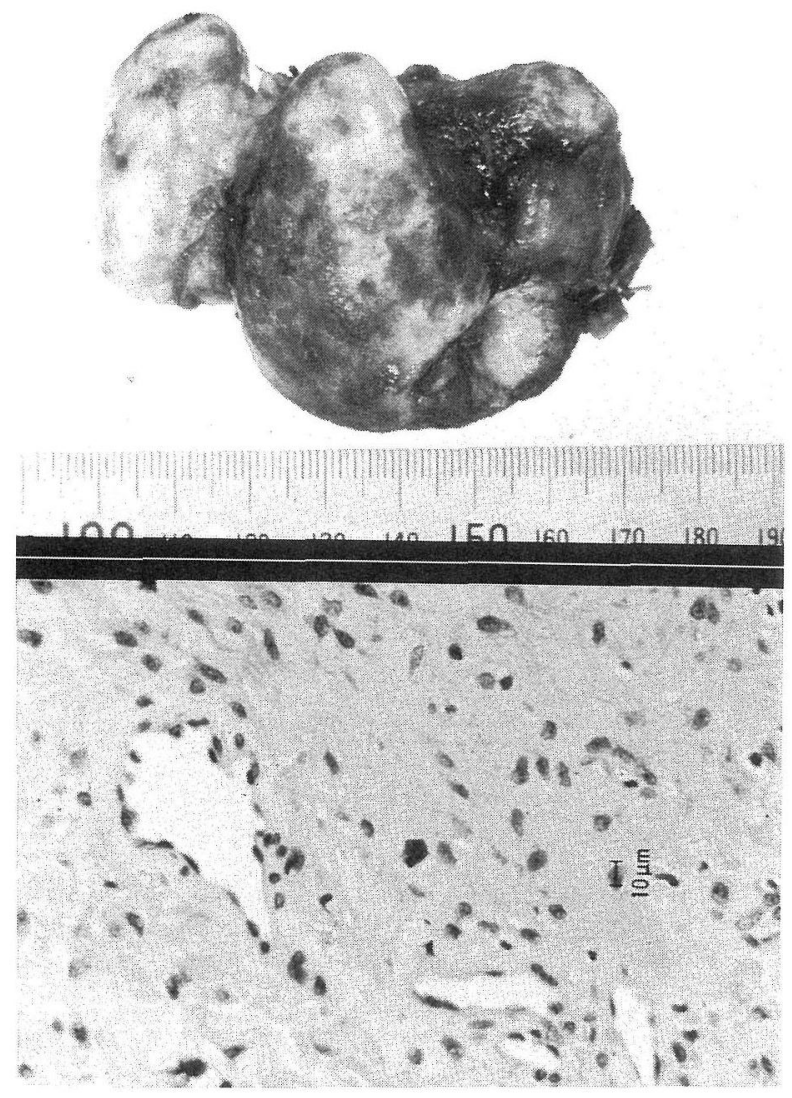

図 5 上: 摘出標本

下: 病理組織(HE 染色, 100倍) 壁の薄い血管と線維性基質の増生を認める.
手術療法の他に, 放射線療法も報告されている2゙が，放 射線療法による下垂体機能の低下3)，腫瘍の悪性転化の 可能性4)などの合併症を考光れば, 腫瘍が頭蓋内に進展 して手術が不可能な場合などを除けば外科的切除による 完全摘出が第一選択である.

外科的切除の際は, 出血量を最小限にして, 完全摘出 のための十分な視野が得られる最適のアプローチ方法を 選択するために, 術前に, CT や MRI で進展範囲を評 価しアプローチ方法の決定を行い5), さらに血管造影に よって栄養血管を同定し, 可能ならばその栄養血管に対 する塞栓術を行らことが必要とされている6)。また，若 年者に好発する腫瘍のため，手術方法は美容上めるいは 顔面などの発達上問題の少ないものでなければならな (7)。乙かし本症例では, 前医での手術で術中に外頸動 脈を結紮されて掠り，また，内頸動脈から腫瘍に対する 血流は認められるものの，はっきりとした栄養血管はな かったため術前の塞栓術は施行できなかった. 腫瘍の進 展範囲と血管造影の結果とから, 出血量が多くなること が予想されたため, 広い視野を得ることと, 美容上の問 題とを両立させるため, 本症例では, midfacial degloving 特よび Le Fort I 型骨切りによるアプローチを選択 した. midfacial degloving 和よび Le Fort I 型骨切り術 を併用するアプローチ方法は, Conley ら ${ }^{8)}$ や Maniglia9) が鼻咽腔血管線維腫を含む上咽頭, 鼻腔, 副鼻腔の腫瘍 の摘出に用いる方法として報告して以来, 鼻咽腔血管線 
維腫の摘出に用いられ，本邦でも林ら ${ }^{10)}$ がこの方法に よる鼻咽腔血管線維腫の摘出例を報告している. 顔面に 外切開を加兄る側鼻切開に比べて顔面に傷が残らないと いら利点があり, その上, 両側上顎洞前壁を露出し, 外 鼻軟骨を持ち上げて上顎骨を上下に開創するので，鼻副 鼻腔を十分な視野のもとに抮くことができ，再発率にお いても側鼻切開と変わらないといら報告もみら.れる5).

Maniglia9) ${ }^{9}$ 経口抻管で手術可能であるとしているが， 本症例では抻管チューブに邪魔されずにより広く開創す るために, 気管切開を行って手術に臨んだ.このアプロー チ法の問題点は顔面の発達障害だが7, 骨の固定に使用 するチタンプレートの数を少なく短くすることによって 障害を最小限にできるとされ7), 本症例では前医での手 術で右上顎洞前壁がなかったこともあり, 固定は 2 本の チタンプレートで左上頸洞前壁にの久行った。 また，上 顎歯槽への血流を確保するための口蓋動脈の温存は必ず しも必要ないと報告されているが9)，本症例では段階的 に上顎骨を開創することにより，口蓋動脈の温存に努め た. 患側の口蓋動脈は腫瘍摘出の際に切断したものの, 健側の口蓋動脈は温存でき, 上䋶歯槽の壊死などは起 こっていない.

手術によるアプローチ法には他に, 内視鏡手術 ${ }^{11}$, 経 口蓋法 ${ }^{12)}$, 経上顎洞法 ${ }^{13)}$, 経側頭下窩法 ${ }^{14)}$ などがある. 内視鏡手術は，侵襲は少ないものの上䋶洞や翼突窩，側 頭下窩に及ぶような大きな腫瘍には適さず，視野が狭い ために, 術前の血管塞栓術が必須となる77. また, 経口 蓋法は外側や前方への進展例には適さない。経上顎洞法 も翼突窩へのアプローチには適さず，本例の場合十分な 視野が得られない。これらに対して, 本症例で行った midfacial degloving とLe Fort I 型骨切り術を併用す れば，翼突窩へのアプローチは確保され，ある程度外側 まで視野に入れることができ, 本症例のように, 翼突窩 一広範に進展する鼻咽腔血管線維腫でも, 美容上の問題 と視野の問題を解決することができる．経側頭下窩法は, 中頭蓋窩, 側頭下窩へのアプローチとして優れて括り， 単独で用いられるほか, Le Fort I 型のアプローチでも 十分な視野が得られない場合に併用するとよいとされて いる15)。本症例でも，十分な視野を得られない場合は経 側頭下窩法を追加する予定で手術に臨んだ．腫瘍の進展 範囲に応じて用いられるアプローチは決定されるべきで あろら。

また，本症例の手術に拈いては，大量出血に備兄，低
血圧麻酔で手術を行らと共に術前に自己血を $1600 \mathrm{ml}$ 準 備した．実際，術中の出血量は $2250 \mathrm{~g}$ に及んだが，自 己血の久の輸血で対応でき，若年者に対する手術の際の 自己血輸血の有用性を認識した.

\section{まとめ}

鼻咽腔血管線維腫の広範な再発例に対して, midfacial degloving 拉よび Le Fort I 型骨切り術を併用し， 出血を最小限にとどめ, 美容的にも満足のいく腫瘍摘出 が可能であったので，報告した。

な括, 本論文の要旨は第 9 回頭頸部外科学会(1999年 1 月, 千葉市)に拈いてロ演した。

\section{参考文献}

1) Sessions RB, Bryan RN, Naclerio RM, et al : Radiographic staging of juvenile angiofibroma. Head Neck Surg 3 : 279 283, 1981.

2 ) Briant TD, Fitzpatrick PJ, and Berman J : Nasopharyngeal angiofibroma; a twenty year study. Laryngoscope $88: 1247 \sim 1251,1978$.

3 ) Gantz B, Seid AB and Weber RS : Nasopharyngeal angiofibroma. Head Neck $14: 67 \sim 71,1992$.

4 ) Donald PJ : Sarcomatous degeneration in a nasopharyngeal angiofibroma. Otolaryngol Head Neck Surg $87: 42$ $\sim 46,1979$.

5 ) Radkowski D, McGill T, Healy GB, et al : Angiofibroma ; changes in staging and treatment. Arch Otolaryngol Head Neck Surg $122: 122 \sim 129,1996$.

6 ) Moulin G, Chagnaud C, Gras R, et al : Juvenile nasopharyngeal angiofibroma ; comparison of blood loss during removal in embolized group versus nonembolized group. Cardiovasc Intervent Radiol $18:$ 158 161, 1995.

7 ) Fagan JJ, Snyderman CH, Carrau RL, et al : Nasopharyngeal angiofibromas ; selecting a surgical approach. Head Neck $19:$ 391 399, 1997.

8 ) Conley J and Price J : Sublabial approach to the nasal and nasopharyngeal cavities. Am J Surg $138:$ 615 618, 1979.

9 ) Maniglia AJ : Indications and techniques of midfacial degloving ; a 15-year experience. Arch Otolaryngol Head Neck Surg $112: 750 \sim 752,1986$.

10）林 伊吹, 板倉 淳, 山本祐三, 他 : 上咽頭血管線維腫例 一Le Fort I osteotomyの応用一. 耳鼻臨床 $85: 581$ 587, 1992.

11) Kamel RH : Transnasal endoscopic surgery in juvenile nasopharyngeal angiofibroma. J Laryngol Otol 110 : 962 
〜968, 1996.

12) Maharaj D and Fernandes CM : Surgical experience with juvenile nasopharyngeal angiofibroma. Ann Otol Rhinol Laryngol $98: 269 \sim 272,1989$.

13）古市暢夫，金森邦彦，大藤周彦，他：巨大な鼻咽腔血管線 維腫の 2 例と本邦報告例についての文献的考察. 耳喉 44 : 875 890, 1972.

14) Fisch $U:$ The infratemporal fossa approach for nasopharyngeal tumors. Laryngoscope $93: 36 \sim 44,1983$.
15) Browne JD and Messner AH : Lateral orbital/anterior midfacial degloving approach for nasopharyngeal angiofibromas with cavernaous sinus extension. Skull Base Surgery $4: 232 \sim 238,1994$.

$$
\left(\begin{array}{l}
\text { 原稿受付 : 平成 } 11 \text { 年 } 6 \text { 月 } 11 \text { 日 } \\
\text { 原稿採択 : 平成 } 11 \text { 年 } 7 \text { 月 } 21 \text { 日 } \\
\text { 別刷請求先 : 山本典生 } \\
\text { † } 632-8552 \text { 天理市三島町 } 200 \\
\text { 天理よろつ相談所病院耳鼻咽喉科 }
\end{array}\right)
$$

